233 JACOB ØLGAARD NYBOE

Ph.d.-studerende

Institut for Nordiske Studier og Sprogvidenskab, Københavns Universitet

\title{
COVERETS KAPITAL
}

\section{En empirisk undersøgelse af genremærkatens betydning for vurderingen af det litterære værk}

Bøger er varer, og det er således centralt for en bogs eksistensberettigelse, at nogen køber den; kun derved realiseres dens potentiale. Bogen har desuden været teknisk reproducerbar i adskillige århundreder, hvorfor vi har vænnet os til en masseproduktion, der kan gennemføres relativt nemt og billigt. En oplagt målestok for et værks succes er derfor antallet af solgte eksemplarer. Samtidig baserer et litterært værks værdi og anerkendelse sig ikke kun på dets kommercielle gennemslagskraft. Hvem der læser det, og hvor det omtales, er nok så væsentligt. Det tab af aura, der ifølge Walter Benjamin (18) knytter sig til den tekniske reproduktion, kan på en vis måde kompenseres ved udgivelsen af små eksklusive oplag - eventuelt med en understregning af bogens særegenhed via fx særlige visuelle eller taktile kvaliteter. Et lavt salgstal kan desuden opvejes af gode anmeldelser, akademisk interesse og opmærksomhed i de rette kredse. Den beskedne økonomiske kapital, som en given udgivelse måtte generere, suppleres dermed af feltspecifik kulturel og social kapital (Bourdieu, "Ökonomisches Kapital" 185f), der så i visse tilfælde kan veksles til økonomisk kapital i form af foredrag, kulturpriser, statslige legater og anden afledt indkomst. Som Bourdieu bemærker: 
Det er således læsernes sociale beskaffenhed (især målt på størrelse) og den symbolske nytteværdi, den repræsenterer, der afgør den præcise rangorden mellem værker og forfattere inden for de enkelte genrer, og her svarer de hierarkiserede kategorier ganske nøje til den sociale rangorden mellem de forskellige grupper af læsere. (Les règles de l'art 168, min oversættelse) ${ }^{1}$

Forbrugerens status smitter altså af på det pågældende produkt. Denne proces gælder også den anden vej, således at forbrugeren ved at læse de "rigtige" bøger kan demonstrere en særlig smag, der er med til at opbygge eller konsolidere en eftertragtet social position (jf. Phillips 2of). Handel med bøger er samtidig en forhandling af status, hvor der udveksles andre kapitalformer end den rent pekuniære. I forlængelse af Bourdieu beskriver Joe Moran, hvordan forfattere må navigere mellem hhv. et autonomt og et heteronomt underfelt. Her har førstnævnte fokus på kunstnerisk integritet og autonomi samt det karismatiske og unikke udtryk (og den unikke udøver), mens sidstnævnte mere er styret af kommerciel succes og salgstal (5). Der er således tale om to poler, hvor der opereres efter forskellige og delvist modsatrettede mekanismer, der kun meget vanskeligt og sjældent kan forenes (7). ${ }^{2}$ I en teoretisk beslægtet undersøgelse demonstrerer John B. Thompson, hvordan den moderne anglo-amerikanske forlagsverden opererer efter en række logikker, der skaber rum for forskellige typer af aktører. De enkelte forlag trækker således på en række forskellige kapitaler $(5),{ }^{3}$ og for forlaget kan den enkelte bog og forfatter repræsentere en økonomisk såvel som en symbolsk værdi, imellem hvilke der er en intrikat vekselvirkning (10f). Heri ligger også forklaringen på, at små, uafhængige forlag er i vækst og trives, mens der samtidig sker en centralisering blandt de mere pengestærke aktører på markedet (152). Små forlag med en klar profil kan således kompensere for manglende økonomiske kapital ved en strategisk udnyttelse af sociale og symbolske kapitalformer (155f).

1 Tak til cand.ling.merc. Eva Bertram for hjælp ved oversættelse af franske citater.

2 Det er blandt andet Morans ærinde at undersøge, hvordan kun en særlig kategori af stjerneforfattere formår i et eller andet omfang at spænde over de to underfelter - som ambivalente og grænseoverskridende figurer i miljøet (7).

3 Thompson opererer med økonomisk, human, social, intellektuel og symbolsk kapital, der naturligvis interagerer. 
For at etablere denne komplekse udveksling af forskellige kapitaler samt positionering i feltet, må bogen formå at sende de rigtige signaler til de rigtige modtagere, og til den opgave er omslagets paratekstuelle elementer ét centralt redskab - og salgsargument (Yampbell 356). Genremærkaten er et oplagt middel til at målrette mod en specifik, mindre gruppe ( $\mathrm{fx}$ digtelskerne) eller markere bred publikumsappel gennem en populærgenre. Den kan med andre ord placere den enkelte bog inden for velkendte rammer og tilbyde forbrugeren et fikspunkt i dennes navigering på markedet. I Claire Squires' formulering er "genre en essentiel komponent på markedet, da den er et af de primære midler, gennem hvilket forfattere og læsere kan kommunikere" (70, min oversættelse). Dermed bliver genremærkaten "en strategi i konstruktionen af kulturel værdi" (71). Genremærkaten kan dog også bevidst bryde med etablerede kategorier (fx "uroman" eller "kontrafaktisk selvbiografi"), hvormed den får karakter af en genresignatur (Nyboe 21f). Her ligger en potentiel appel til en mere nysgerrig forbrugertype - den litterære feinschmecker, der er pirres af en mere udfordrende paratekst. ${ }^{4}$ På den måde bliver genremærkaten også et sted, hvor bogen kan signalere, hvilken form for kapital der har dens primære interesse, og hvilket underfelt den primært placerer sig i. I det følgende skal det via en spørgeskemaundersøgelse udforskes, hvordan forsiden påvirker fire bøgers appel med særlig fokus på genremærkatens rolle. Samtidig bliver det en lokal undersøgelse af, hvordan smagsmæssige distinktioner stadig er i spil her på tidsmæssig såvel som geografisk afstand af Bourdieus Frankrig.

\section{FORSØGSDESIGN}

Det elektroniske spørgeskema $(n=539)$ blev distribueret af SurveyXact (Rambøll) med en lige vægtning af de tre demografiske variable køn, alder og geografi. Undersøgelsens hoveddel bestod i, at respondenterne skulle forholde sig til forsiderne fra Svend Åge Madsens Pigen i cementblanderen (PIC), Jakob Vedelsbys Du og jeg (DOJ), Jesper Steins Akrash (AKR) og Maja Lee Langvads Hun er vred (HEV) (figur 1). På den baggrund skulle de vur-

4 Squires har også øje for den flertydige genremarkering som markedsføringsstrategi og potentiel finkulturel indikator (82). 


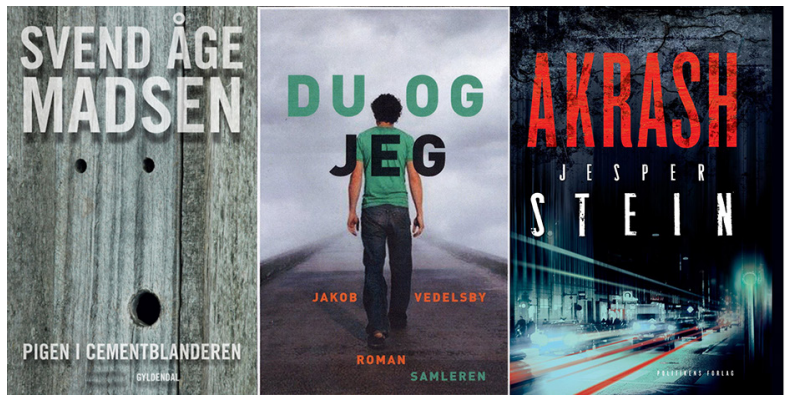

$\underset{\text { Et vidnesbyrd om transnational adoption }}{\text { HUN ER VRED }}$

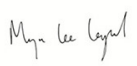

Fig. 1. Forsider brugt i gruppe 1

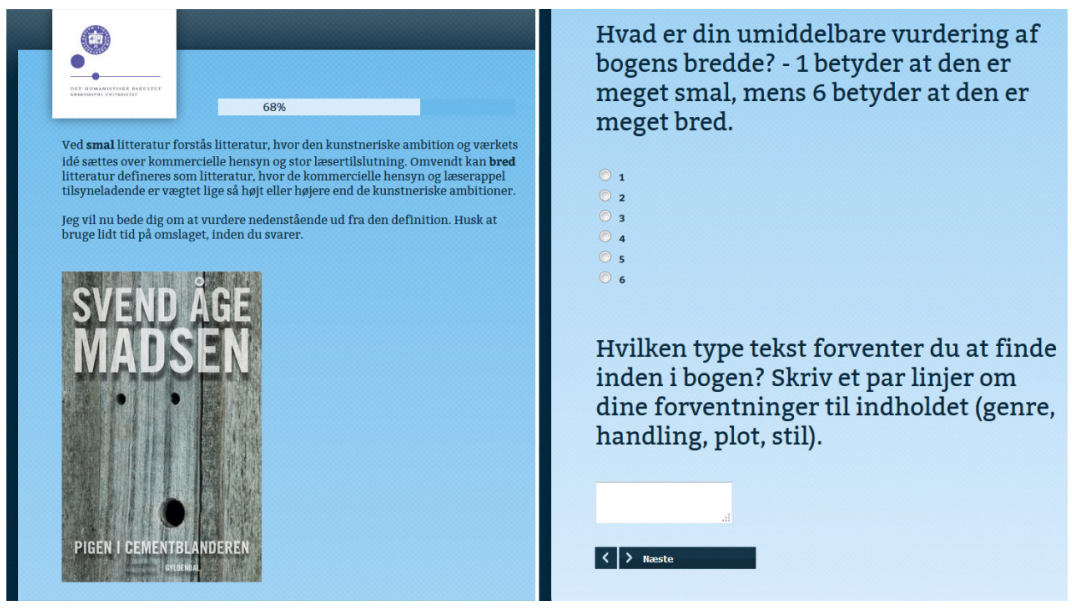

Fig. 2. Eksempel på spørgsmål med brugerflade

dere bogens bredde på en skala fra 1 til 6 og komme med et bud på en kort karakteristik i fritekst (figur 2). ${ }^{5}$

Respondenterne blev inddelt i to grupper, for hvilke spørgsmålene var helt identiske på nær en væsentlig detalje: For gruppe 1 (n=263) var genresignaturen 'mikroman' bortredigeret fra PIC og krimimærkaten fra $A K R$, mens der i gruppe $2(n=276)$ var fjernet romanmærkaten fra DOJ

5 Spørgeskemaet i dets helhed er tilgængeligt her http://genre.ku.dk/publications/ Bilag_1-3.pdf (bilag 1, s. 1-23) tillige med samtlige besvarelser (bilag 2, s. 24-65). 


\section{JACOB ØLGAARD NYBOE COVERETS KAPITAL}

og genresignaturen 'et vidnesbyrd om transnational adoption' fra HEV. Det bliver hermed muligt at undersøge, om genremærkaten spiller en signifikant forskel for opfattelsen af bogen, ved sammenligning af de to grupper (en skematisk oversigt for grupperne gives i tabel 1). ${ }^{6}$ Foruden de undersøgelsesspecifikke spørgsmål blev respondenterne spurgt til baggrundsvariablerne alder, uddannelsesniveau, eventuel skønlitterær uddannelses- eller arbejdserfaring, læsemotivation, læsevaner samt eventuelt forhåndskendskab til forfatterne. Spørgsmålene blev inden brug testet via otte kognitive interview (jf. Collins; Willis; Drennan).

FORSIDE

Pigen i cementblanderen (PIC)

Du og jeg (DOJ)

Akrash (AKR)

Hun er vred (HEV)
GENREMÆRKAT/-SIGNATUR

Mikroman (genresignatur)

Roman

Krimi

Et vidnesbyrd om transnational Med adoption (genresignatur)
GRUPPE 1 GRUPPE 2

Uden Med

Med Uden

Uden Med

Uden

Tabel 1. Fordeling af genremærkater i de to grupper

\section{BAGGRUND OG HYPOTESER}

Der er i forskningen en etableret bevidsthed om, at vi ikke møder tekster som rent abstrakte størrelser, der transmitteres direkte til vores fortolkende bevidstheder, men at vi tilgår dem via dokumenter, der tilføjer betydning ved deres materialitet og paratekstuelle kontekst (Genette; McGann; Kondrup; Bjerring-Hansen og Jelsbak). Det åbner for et retorisk perspektiv, hvor forfatteren (og/eller udgiverne) har mulighed for at indgå i en forhandling med læserne om opfattelsen af og forventningerne til det litterære værk via de bibliografiske koder (McGann 12) og paratekstens transmissionsrum (Genette 2f). Der er imidlertid kun ganske lidt forskning, der har har testet de teoretiske hypoteser om paratekstens betydning empirisk ved at undersøge, hvorvidt og hvordan parateksten påvirker receptionen hos

6 De to grupper adskiller sig ikke signifikant, hvad angår uddannelse, alder og køn. Det fremgår af $\chi^{2}$-test (jf. Field 688f), der sammen med øvrige statistiske test er tilgængelige her http://genre.ku.dk/publications/Bilag_1-3.pdf (bilag 3, s. 66-73). 
238 KULTUR \& KLASSE * $124 * 2017$

HANDEL

faktiske læsere. ${ }^{7}$ Dixon, Bortolussi, og Mullins demonstrerer, hvordan kendere af hhv. science-fiction og krimier kompetent klassificerer bøger i disse genrer ud fra deres covers. I et beslægtet studie viser Piters og Stokmans, hvordan læsere i vid udstrækning genreklassificerer bøger i overensstemmelse med den officielle hollandske genrestandard, mens en tese om, at de mest genretypiske bøger også er de mest foretrukne, kun bliver delvist bekræftet. ${ }^{8}$ Skønt ingen af dem inddrager egentlig forbrugerrespons, er det desuden værd at nævne tre undersøgelser af relationen mellem paratekst og marked. Moretti demonstrerer på baggrund af 7000 romantitler, hvorledes titlernes længde er aftaget i takt med romanmarkedets ekspansion og publikums tilvænning til genren. Tilsvarende undersøger Lundblad det dekorerede lærredsbinds opblomstring i bogbranchen som en konsekvens af en stigende kommercialisering og et behov for en målrettet promovering og positionering af de enkelte bøger (169). Endelig undersøger Squires litteraturens markedsføringsmekanismer, som de udfolder sig i krydsfeltet mellem forskellige aktører og paratekstuelle signaler. Ikke mindst fremhæver hun genresignaler, der både formes af og virker tilbage på de øvrige faktorer. Min interesse er i vid udstrækning sammenfaldende med de tre sidstnævnte studier, mens de to førstnævnte repræsenterer en empirisk-metodisk tilgang, som jeg lægger mig i forlængelse af.

Genremærkaten kan i form af en genresignatur påkalde sig ekstra opmærksomhed og øge sit betydningspotentiale. Sådanne genresignaturer optræder på to af forsiderne, nemlig hhv. mikroman (PIC) og vidnesbyrd om transnational adoption (HEV). Gennem genresignaturen sker en særpositionering af værket, der hævdes at overskride de gængse genreskel. På denne baggrund opstilles følgende hypoteser for den videre undersøgelse:

$\mathrm{H}_{1}$ : Forsiderne af PIC og HEV vil have smallere appel i originaludgaven end i deres redigerede version, hvor genresignaturen er fjernet.

7 David Miall taler om en tendens til at "opfatte, hvad der i virkeligheden er empiriske spørgsmål, som aksiomatiske" (12, min oversættelse).

8 Studiet lider desværre af metodiske problemer i form af en lille respondentgruppe ( $\mathrm{n}=32$ ), der yderligere inddeles i hhv. hyppige og ikke-hyppige læsere ud fra et potentielt problematisk princip (Piters og Stokmans 162). 
$\mathrm{H}_{2}$ : Omvendt vil DOJ og Akrash blive opfattet som bredere på baggrund af originalforsiderne med de velkendte genremærkater end i de redigerede udgaver, hvor disse er fjernet.

$\mathrm{H}_{3}$ : Internt blandt originalforsiderne (alle med genremærkater) forventes følgende appelmæssige rangorden: AKR (bredeste vurdering), DOJ, PIC, HEV (smalleste vurdering).

Som baggrund for $\mathrm{H}_{1}$ ligger ovenstående betragtninger om eksklusivitetsmarkering og det forhold, at genresignaturen indebærer en vis metarefleksivitet og øget formfokus, hvilket typisk appellerer til et mere elitært smagsmønster (Bourdieu, La distinction 30f). $\mathrm{H}_{2}$ bygger på hhv. roman- og krimigenrens status som bredt favnende genrer, der især for sidstnævntes vedkommende også afspejler sig i høje salgstal (Genette 97; Fowler 109; T.

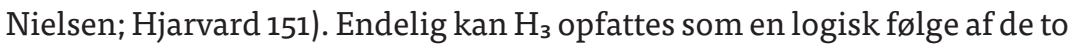
forudgående, idet det vurderes, at PIC fremstår mere tilgængelig end HEV grundet illustration, forfatternavn og forlag.

\section{HOVEDRESULTATER - KVANTITATIV ANALYSE}

Hypotese 1 og 2 blev testet ved forside for forside at sammenligne de to grupper via en ensidet, uafhængig t-test (Field 324ff). Ved testen vurderes, hvorvidt den ene middelværdi $\mu_{1}$ afviger signifikant fra den anden $\mu_{2}$ ud fra nulhypotesen, at de to middelværdier er ens $\left(\mathrm{H}_{0}: \mu_{1}=\mu_{2}\right)$. Jo større en middelværdi desto bredere vurdering, hvorfor vores alternative hypotese (forsøgshypotesen) for AKR er $\mu_{1}<\mu_{2}$ (bredest vurdering i gruppe 2 med krimimærkaten). Denne test gav en $\mathrm{p}$-værdi langt under et signifikansniveau på $5 \%(\mathrm{p}=0,00000033 \%)$ med de to beregnede middelværdier $\mu_{1}=3,98$ og $\mu_{2}=4,71$. Der er altså signifikant belæg for, at krimimærkaten medfører en bredere vurdering. Et lignende mønster ses for DOJ, hvor den alternative hypotese er $\mu_{1}>\mu_{2}$ (bredest vurdering i gruppe 1 med romanmærkat). Også her er p-værdien under $5 \%$ $(\mathrm{p}=3,5 \%)$ med middelværdierne $\mu_{1}=3,13$ og $\mu_{2}=2,93$. Vi har altså grund til at antage, at romanmærkaten medfører en bredere appel.

Hvor arbejdshypoteserne blev entydigt bekræftet ovenfor, er billedet en smule mere komplekst, når vi betragter forsiderne med genresignatur. I tilfældet PIC er den alternative hypotese, at $\mu_{1}>\mu_{2}$ (bredest vurdering i 
240 KULTUR \& KLASSE * $124 * 2017$

HANDEL

gruppe 1 uden genresignatur). Denne test gav en p-værdi på 7,9\% med de to beregnede middelværdier $\mu_{1}=3,57$ og $\mu_{2}=3,40$. Her er p-værdien altså over et signifikansniveau på $5 \%$, men stadig under $10 \%$, hvilket kan forsvares som signifikansniveau i en lavrisikoundersøgelse som denne (jf. Field 51). Undersøgelsen peger således med forbehold på, at genresignaturen $i$ dette tilfælde signalerer smalhed. For HEV er den alternative hypotese $\mu_{1}$ $<\mu_{2}$ (bredest vurdering i gruppe 2 uden genresignatur). Her giver testen imidlertid en $\mathrm{p}$-værdi langt over ethvert rimeligt signifikansniveau ( $\mathrm{p}=$ $98,1 \%)$, og det bemærkes, at $\mu_{1}=2,28$ faktisk er højere end $\mu_{2}=2,05$. Der er således intet belæg for vores hypotese, men det påfaldende resultat giver anledning til at teste den omvendte alternative hypotese: $\mu_{1}>\mu_{2}$ (bredheden er højest i gruppe 1 med genresignatur). Denne test giver en p-værdi under $5 \%(1,9 \%)$. Det viser sig altså, at der imod forventning er belæg for, at bogen fremstår mere bred med genresignatur end uden.

Vender vi blikket mod de fire originalforsider, kan de sammenlignes parvist, hvis blot vi sætter signifikansniveauet ned til $1 \% .{ }^{9}$ Vi må dog først revidere den oprindelige hypotese en smule på baggrund af middelværdierne (se tabel 2).

BOG

AKR

PIC

DOJ

HEV

Middelværdi

4,71

3,40

3,13

2,28

Tabel 2.Bredhedsvurdering af originalforsiderne (middelværdier)

Ganske som forventet ligger AKR øverst og HEV nederst i forhold til bredhedsvurdering, men midterpositionerne er byttet om i forhold til arbejdshypotesen, idet PIC vurderes som mere bred end DOJ. I vores t-test sammenlignes således parvist AKR over for PIC, PIC over for DOJ og DOJ overfor for HEV med de alternative hypoteser, at middelværdien for førsteleddet er højest. Disse tre test giver alle p-værdier under $1 \%$ (p = o,8\% for PIC/ DOJ-testen og langt lavere for to andre). Der er altså signifikant forskel på vurderingen af de fire originalforsider, men rangordnen afviger let fra den oprindeligt antagne.

9 Signifikansniveauet sænkes for at modvirke en forhøjet risiko for type 1 fejl grundet antallet af kategorier (jf. Field 348). 


\section{JACOB ØLGAARD NYBOE}

COVERETS KAPITAL

\section{ANDRE RESULTATER}

I besvarelsen af, hvilken type tekst man ville forvente af PIC, er "krimi" i begge grupper det mest hyppige svarelement, der optræder hhv. 120 (gruppe 1) og 117 (gruppe 2) gange. Når parateksten så tydeligt markerer krimitræk, skyldes det formentlig en blanding af titlens spil på Adler-Olsens Kvinden $i$ buret ${ }^{10}$ og illustrationen. Sidstnævnte antyder en gåde og sætter læseren i en art belureposition via knasthullerne i træplankeværket, der henleder fantasien på, hvad der kunne tænkes at gemme sig på den anden side. Samtidig danner disse huller ved deres indbyrdes placering et stiliseret ansigt med åben mund, hvilket kan give yderligere spænding/chok-associationer. Den næsthyppigste svartype er variationer over "ved ikke" (fx "?" og "ingen anelse") med hhv. 32 og 31 forekomster. I de her fremlagte hovedtendenser er de to grupper forbløffende ens. En forskel er dog, at flere i gruppe 2 forventer en krimi af en let usædvanlig karakter: "måske en slags antikrimi", "krimi skrevet på et højere niveau", "krimi med intelligent plot", "En anderledes krimi, måske med lidt overnaturlige/sci-fi indslag" og "Kriminal mikroroman" (direkte reference til genresignaturen). I det hele taget er der i højere grad forventninger om, at der er noget særligt på spil: "ud over det sædvanlige", "spidsfindig fortælling", "snørklet og sikkert springende i tid", "underfundig, intellektuelt udfordrende" og "persongalleri hvor skæbner væves sammen til en samlet fortælling". Der forekommer også forventninger til en legesyg og let eksperimenterende tekst i gruppe 1, men i mindre grad og da typisk knyttet til forhåndskendskab til forfatteren. I en handelsmæssig optik knytter forsiden altså an til det potentielt lukrative krimimarked og opbygger læserforventning om et vist spændingsniveau. Samtidig nuanceres dette indtryk af andre signaler, der forhindrer, at værket bliver sat i en ren mainstream-kategori. Den effekt ses stærkest i udgaven med genresignatur, hvilket forklarer den smallere vurdering her.

For DOJ er der i begge grupper flere "ved ikke"-besvarelser end for PIC; hhv. 45 og 49. Generelt er billedet mere spredt, når det kommer til genrebestemmelse, hvor "kærlighedsroman"11 er den mest hyppige med 21 forekomster i gruppe 1 (med mærkat) over for kun 15 i gruppe 2. Forde-

11 Enkelte forekomster af parforholdsroman og kærlighedshistorie er inkluderet her. 
242 KULTUR \& KLASSE * $124 * 2017$

HANDEL

lingen af romanangivelser (uden undergenre) er 9 over for 10. Derudover forekommer en række genrekategorier i begge grupper: (selv)biografi (6/9), ungdomsbog (6/3), krimi (3/1), digte (1/2), selvhjælps-/livsstilsbog (1/1), novelle (o/1) og undervisningsmateriale (o/1). Det kan konstateres, at forsiden sender mindre entydige signaler end i PIC's tilfælde, og desuden, at genremærkaten i gruppe 1 i enkelte tilfælde er blevet enten overset eller underkendt. Indtrykket af en svært afkodelig forside går igen i de mange indholds- og stilbeskrivelser, der blandt andet dækker over: socialrealisme, filosofisk roman, skildring af en skizofren person, lidt svulmende tekst (om følelser), samfundskritik, mellemmenneskelige problemstillinger, begær, trist, psykologisk og navlepillende. Den store spredning vidner for gruppe 1's vedkommende om en relativ stor spændvidde for opfattelsen af romangenren (jf. Fowler 120). En ren negativ valorisering (egotrip, sej at komme igennem, tungere læsning, kedelig, navlepillende) forekommer næsten kun i gruppe 2, hvilket korresponderer med den generelt smallere vurdering i denne gruppe. Men selv med genremærkaten vidner de vage og spredte karakteristikker om en forside, der har svært ved at etablere en klar profil i forhold til markedet.

Der tegner sig et noget klarere billede for AKR, hvor der også er distinkte forskelle mellem de to grupper. Den mest hyppige genremærkat er "krimi" (72 for gruppe 1 og 133 for gruppe 2) og den næsthyppigste markering er "ved ikke" (47/26). Blandt de uafklarede nævnes titlens uigennemskuelighed hyppigt som begrundelse. I gruppe 1 figurerer også en række andre genrebetegnelser, der dog typisk er plot- og spændingsorienterede: thriller, spændingsroman, (psykologisk) gyser, knaldroman. Den højfrekvente benævnelse af krimi og beslægtede genrer i gruppe 1 demonstrerer, at forsiden sender klare signaler selv uden genremærkat, hvilket bekræfter en særlig, letgenkendelig krimiæstetik (også påvist i Piters og Stokmans), som forlagene kan udnytte (hvilket de også gør, jf. Bendsen). Beskrivelser af temaer og stil er mest udfoldet i denne gruppe, men der er genkommende træk i begge grupper: storby, natteliv, action, kulturmøde/indvandring, underverden/gangstere. Der er flest kommentarer til stilistikken i gruppe 2 (med mærkat), og disse går i reglen på tilgængelighed og bred appel: "popularistisk litteratur, svagt sprogligt fokus", "Overkommelig for de fleste", "'sort/hvid' på den letlæste måde", " henvender sig til det BREDE publikum", 


\section{JACOB $\varnothing L G A A R D$ NYBOE COVERETS KAPITAL}

"sproglig enkel", "Så er alle med" osv. Der afslører sig her en række fordomme, som nogle respondenter nærer til krimigenren, og de er stærkest, når krimimærkaten forekommer. Generelt er AKR klart profileret i forhold til det heteronome underfelt, men med en tydelig forskel mellem de to grupper som afspejlet i forskellen i bredhedsvurderingerne.

For HEV er "ved ikke"-kategorien igen den mest hyppige med hele 68 forekomster i gruppe 2 (uden genresignatur) og 37 i gruppe 1. Der er generelt tydelige forskelle mellem de to grupper samtidig med, at der er relativ stor intern spredning i grupperne. Fx har 30 respondenter i gruppe 1 gættet på, at der er tale om digte (inklusiv poesi og digtsamling), mens det kun er 3 i gruppe 2. Omvendt har 27 i gruppe 2 gættet på (selv)biografi, der kun forekommer 7 gange i gruppe 1. I gruppe 1 optræder til gengæld 13 forekomster af "fagbog" /"dokumentar" og 8 indikationer af en blandingsgenre mellem fiktion og fakta ( $\mathrm{fx}$ "autofiktion" og "faktion"), der slet ikke er repræsenteret i gruppe 2. I gruppe 1 er genresignaturen synlig i form af hyppige benævnelser af et adoptionstema (fx "En hård fortælling om adoption"), der er fraværende i gruppe 2. Her optræder i stedet en kvindeog kønstematik flere steder: "Kvindelitteratur af den intellektuelle slags", "Kvindebog", "av min livmoder", "kvinders følelsesliv" o.l.. Stilistisk er der i gruppe 1 forventninger om sværttilgængelig tekst med et lille publikum: "smal", "højtravende", "stilistisk højere lix-tal", "svært sprog". Det billede går til dels igen i gruppe 2 (jf. lav bredhedsvurdering for begge grupper), men her iblandet minimalismetræk og generelt lidt mere variation i buddene: "minimalistisk", "alternativ skrivestil", "ENKEL SMÅTSKÅRET INDADVENDT", "Et blankt lærred", "intellektuelt udfordrende", "Uha - det er for viderekomne" etc.. I denne gruppe nævnes det simple, illustrationsløse omslag eksplicit ("Intet foto udenpå. Ser 'klogere' ud på reolen"), og dette har som påpeget også resulteret i en del usikkerhed i klassificeringen, men i enkelte tilfælde har underdetermineringen ført til præcise, detaljerede karakteristikker som denne:

En digtsamling skrevet i et flot, kompliceret sprog - ikke med rim, som er ens i hver vers / strofe. Digtene belyser en kvindes vrede omkring en konkret problematik [...] Der vil være et digt på hver side, måske kun på det højre blad, sådan at digtet er parat når blades vendes. 
244 KULTUR \& KLASSE * $124 * 2017$

HANDEL

Fraværet af paratekstuelle signaler kan altså i sig selv være et virkningsfuldt signal, der pirrer fantasien. HEV formår i begge forsideudgaver at markere sig klart som netop et nicheprodukt (solidt placeret i det autonome underfelt). Der er ikke forventning om et stort marked, men dog om et marked med et ret veldefineret publikum - der til gengæld varierer alt efter om genresignaturen er tilstedeværende.

\section{DISKUSSION}

Det fremgår, at genremærkaten har en klar betydning for en bogs publikumsappel, men også at den suppleres af en række andre paratekstuelle signaler, hvoraf flere nævnes eksplicit i prosasvarene. Dette fremgår fx tydeligt af vurderingen af PIC, hvor kombinationen af titel og illustration sender et krimisignal, der så modificeres eller korrigeres af forfatternavn og genresignatur (i gruppe 2). PIC formår således i en vis udstrækning at balancere mellem de to underfelter hos Moran, idet den både trækker på krimigenrens løfter om spændingselementer og en relativt lettilgængelig plotstruktur og samtidig signalerer kunstnerisk ambition og stilistisk særegenhed. Dette afspejler sig i et relativt højt oplagstal på 2500 eksemplarer (venligst oplyst af forlaget) kombineret med positive anmeldelser af veletablerede anmeldere i de store dagblade (jf. Bukdahl; Handesten; Skyum-Nielsen; Vinterberg; Rosendahl; J. Christensen). ${ }^{12}$ Man kan argumentere for, at det er et kendetegn for den sene Madsen at kombinere den kulørte, folkelige fortælling med stilistisk opfindsomhed og intellektuelt vingefang. Vi har således at gøre med en forfatter, der vellykket formår at generere økonomisk kapital og samtidig bevare en høj feltspecifik symbolsk kapital (fx er Tugt og utugt i mellemtiden udkommet i sjette oplag, og der foreligger en omfattende litteratur og tilmed en doktordisputats (Gemzøe) om forfatterskabet). Madsen er samtidig den mest kendte af forfatterne (20 \%) og den, hvis navn optager klart mest plads på forsiden. Dette peger på forfatternavnet som et potentielt markedsføringsværktøj (jf. Lundblad 174f; Squires 87), og Genette peger da også netop på en positiv sammenhæng mellem en forfatters berømmelse og eksponering af navnet på omslaget 
(39). I Morans terminologi er Madsen således den, der er tættest på at være en stjerneforfatter ved at "indtage et eftertragtet område af kulturel produktion mellem det restriktive og udvidede underfelt" (6, min oversættelse).

I tilfældet AKR blev det overbevisende bekræftet, at krimimærkaten i sig selv er en markant indikator for bred appel. Her er altså potentialet for en god forretning (forudsat at resten af det markedsføringsmæssige maskineri fungerer), og bogen har da også solgt over 30.000 eksemplarer (oplyst af forlaget). Som det fremgår af respondentkommentarerne, er prisen for den kommercielle succes imidlertid en række fordomme angående stilistisk finesse og en forventning om, at der sigtes mod laveste fællesnævner. Udover de ovenfor anførte citater kan nævnes et udsagn som "relativt simpelt sprog, pageturner, ingen dybere mening" og "Den lidt sværere tilgængelige titel indikerer en vis kompleksitet, hvilket garanteret kun er påtaget". Anmeldelserne er generelt positive og fremhæver litterære kvaliteter, men der er også en skarp undtagelse i Weekendavisens anmeldelse, hvor bogen kaldes "kedelig levebrødskrimi", som udarter til "sprogklichéer, der ligeså godt kunne være opereret ud af en lægeroman" (L. B. Nielsen). Her bemærkes, hvordan der slås ned på det forudsigelige, og hvordan bogen nedgøres via sidestilling med en formodet trivialgenre, og i Information er bogen slet ikke anmeldt, hvilket i sig selv er en art domsfældelse. Selv de positive anmeldelser bærer præg af negative genrefordomme, idet det markeres, hvordan kvaliteterne er på trods af og i kontrast til andre aktører inden for genren:

Hvad forfattere udi krimigenren ofte er fattige på, har Jesper Stein med andre ord til overmål: (...) han tør lege med klicheer og personkarakteristik og blande det banale med det dybsindige, det lette med det lærde. (Reinholdt) ${ }^{13}$

Skønt krimien har opnået en vis anerkendelse i dele af det litterære etablissement (jf. fx Stougaard-Nielsen; Elmelund), eksisterer der altså stadig en aktiv distinktion mellem høj- og lavkultur (knyttet til hhv. det autonome og heteronome), der bevirker, at krimier kommer hårdere til den litterære 
246 KULTUR \& KLASSE * $124 * 2017$

HANDEL

anerkendelse. ${ }^{14}$ Finansiel succes og kulturel kapital synes næsten at være modsatrettede størrelser, og Bourdieus udsagn om feltet i slutningen af det nittende århundrede synes altså stadig at have en vis gyldighed: "hierarkiet blandt genrer (og forfattere) i forbindelse med specifikke kriterier for fagfællevurdering er næsten det eksakt modsatte af hierarkiet i forbindelse med kommerciel succes" (Bourdieu, Les règles 165f, min oversættelse).

For romanen så vi ligeledes, at genremærkatens tilstedeværelse medførte en bredere appel. Samtidig fremgik det dog også, at denne genreangivelse i kombination med den ukendte forfatter (kun 5 respondenter kendte til ham på forhånd) og den metaforisk anlagte illustration gav anledning til en vis åbenhed i forhold til en nærmere bestemmelse af teksten. Via respondenternes respons kommer romangenren således til at balancere mellem umiddelbar genkendelighed og mulighed for stor intern variation, hvilket fremgår af spredningen i karakteristikkerne. Her har vi nok også forklaringen på, hvorfor PIC fik en højere bredhedsvurdering end DOJ i modstrid med den oprindelige hypotese: Skønt PIC signalerer legesyge og særegenhed, giver den dog også klare krimiassociationer; og skønt DOJ angiver en vis tilgængelighed ved at kalde sig roman, er den også en lidt ubestemmelig en af slagsen. Igen er vi inde på samspillet mellem forskellige paratekstelementer: Sammenstilling af den samme forside på tværs af respondentgrupper viser den relative effekt af genremærkaten, mens det jo netop er det samlede paratekstuelle indtryk, der sammenlignes de forskellige originalforsider imellem. Især for en ukendt forfatter skal der mere til end en romanmærkat for at blive attraktiv på markedet (det symbolske såvel som det økonomiske), og her lader DOJ ikke til at have haft den fornødne gennemslagskraft - heller ikke i anmeldelserne, der er få og ubegejstrede (Jørgensen; Tetzlaff; Haarder). ${ }^{15}$ Forlaget ønsker ikke at oplyse salgstal, men fire boghandlere i en privat stikprøvekontrol havde ikke solgt et eneste eksemplar, hvilket understøtter billedet af et svagt profileret værk.

14 Squires taler i den forbindelse om, hvordan snobberi og fordomme er knyttet til (foranderlige) genreforestillinger (73).

15 Jørgensen giver to stjerner og taler om "en tynd whiskysjus", mens Tetzlaff karakteriserer den som klichéfuld, og Haarder kun er marginalt mere positiv. Andre anmeldelser i de landsdækkende aviser har ikke kunnet opspores. 
Endelig viste genresignaturen sig at have signifikant betydning for opfattelsen af $\mathrm{HEV}$, men i modsat retning af den faglige forudsigelse. Her viser det stærkt stiliserede, hvide omslag med forfatternavnet som håndskrevet signatur sig at have så stærk en usikkerheds- og eksklusivitetseffekt, at den genreangivende undertitel trods sin atypiske karakter giver et tiltrængt fodfæste. Ved nærmere refleksion synes resultatet således forholdsvist let at forklare, da forsiden uden genresignatur i højere grad udlever det rene, funktionsløse og nonfigurative ideal, der hos Bourdieu udgør et distinktivt træk ved en høj og eksklusiv kunstform over for mere populære udtryk (Bourdieu, La distinction 30f). Skønt forsiden i begge versioner fremstår markant smallere end de øvrige, kan det altså konstateres, at fraværet af genremærkat også kan være en strategi til at skabe genremæssig usikkerhed og påberåbe sig særstatus (jf. Rasmussen 144) - og denne effekt kan altså trumfe en eventuel genresignatur. Respondentsvarene afslører også, hvordan man som litterat kan være præget af egne forudsætninger i hypotesedannelsen, da jeg personligt fokuserede på det interessante i, at et skønlitterære værk spiller på en fakta- og fagbogsdiskurs og selvbetegner sig som vidnesbyrd med alt, hvad det medfører af kompleksitet. Mange af respondenterne opfatter imidlertid teksten som en fagtekst om adoption uden formeksperimenter eller genreblanding. I forhold til en minimalistisk og yderst formbevidst digtsamling, der var en typekarakteristik i den anden gruppe, har bogen alligevel fremstået mindre smal (i overensstemmelse med en historisk position for poesien som markedsmæssigt udgrænset (Bourdieu, Les règles 166)). I den forbindelse er det interessant, at versionen med genresignaturen faktisk blev vurderet lavest, hvis man udelukkende betragter respondenter med en skønlitterær baggrund. ${ }^{16}$ Af anmeldelser fremgår det, at HEVs tydelige mangel på markedsmæssig appel i hvert fald til dels opvejes af anerkendelse fra feltet. I Information fremhæves det således, at der aldrig har eksisteret noget lignende før, og at bogen "føles ligeså mættet og ultimativ som et livsværk" (Yde), for Lars Bukdahl har den på en nærmest genial måde "en integreret hybriditet" (Bukdahl, "Hun er vred over, at hun er vred") og i Politiken tales om en "skønlitterær bedrift - inden

16 Forskellen er ikke signifikant, men alligevel påfaldende ved det, at det generelle resultat her inverteres. 
248 KULTUR \& KLASSE * $124 * 2017$

HANDEL

for genren autobiografisk konceptkunst" (Garsdal). Endnu mere sigende har den også tiltrukket sig mere akademisk interesse (fx C. H. Christensen; Behrendt og Bunch), og bogen er desuden et af hovedeksemplerne i Mette Høegs opgør med, hvad hun ser som en særlig indspist og indadvendt tendens i samtidslitteraturen (Høeg). Forlaget har ikke ønsket at oplyse salgs- eller oplagstal, men bogen er udkommet i en paperbackversion, hvorfor den næppe har været helt uden salgsmæssig succes. Interessant nok kan netop Høegs angreb på bogen faktisk have øget salget, da der bl.a. opstod læsekredse med "kvindelitteratur"-tema i kølvandet på debatten (se fx læseklubben "Ung, dansk, kvinde - og forfatter" (Keinicke)).

De signifikante forskelle i forsidevurderingerne indikerer, at der stadig eksisterer en distinktion mellem høj- og lavkultur, og at man i parateksten kan spille på (og måske ligefrem fastholde eller styrke) denne. Dette understøtter Mike Savages analyse af, hvordan forskelle i kulturel kapital og smagsmæssige klassemarkører ikke er blevet opløst i en postmoderne værdinivellering og almen demokratisering af kulturen, men blot har antaget nye former (102f). ${ }^{17}$ Der kan oplagt suppleres med undersøgelser af, hvordan paratekst (og genremærkat) spiller ind på selve læsningen af bøgerne, hvilket jeg har forsøgt andetsteds (Nyboe, "Den var ikke onkelagtig nok"), ligesom det ville være interessant at følge paratekstens betydning for valg, fravalg og holdningsdannelse i en mere naturlig forbrugssituation - altså ude blandt faktiske kunder på bogmarkedet. Det perspektiv kunne suppleres med en analyse af, hvorvidt og hvordan den paratekstuelle genremarkering spiller en rolle i kritikken, der jo så igen influerer på markedet (jf. Nyboe 29f). Endelig åbnes der op for en mere udfoldet generel diskussion af genre som markedsførings- og forhandlingsværktøj såvel som værdimarkør, hvor der kan være en tendens til at distancere sig fra genreafhængighed, som et resultat af "den værdiladede adskillelse mellem 'generisk' og 'litterær' fiktion" (Squires 71, min oversættelse).

17 Han peger fx på den kulturelle omnivor, der netop ikke vil fremstå snobbet, og for hvem alle kulturprodukter principielt kan have interesse (Savage 114f). Her er der imidlertid stadig en stor bevidsthed om, hvad fra populærkulturen, der tages ind, og ikke mindst om, hvordan det bruges, og desuden går bevægelsen ikke den anden vej - der er stadig kulturprodukter, der er klart markeret som eksklusive (Savage 122f; Handesten, "Der er noget galt i Danmark" 20). 


\section{JACOB ØLGAARD NYBOE COVERETS KAPITAL}

Sammenfattende fremstår det klart, at coveret spiller en central rolle i bogens markedsmæssige positionering. Ikke alene er det med til at indikere bogens potentielle salgbarhed, men det signalerer også værdi inden for andre typer af kapital end den økonomiske. Forsiden spiller således en rolle i handelskredsløbet og herunder den statusmæssige forhandling, der indgår i dette. Denne forhandling kommer i stand som et samspil mellem en række paratekstuelle markører, men som demonstreret kan der påvises en særskilt effekt for genremærkaten. Det gælder også genresignaturerne, der altså både kan indskrænke og udvide fortolkningsrummet i det umiddelbare møde og have ekskluderende såvel som inkluderende signalværdi - alt efter signaturens karakter og den paratekstuelle kontekst.

JACOB ØLGAARD NYBOE. Ph.d.-studerende ved Institut for Nordiske Studier og Sprogvidenskab, Københavns Universitet. Har senest publiceret "The Game of the Name. Genre Labels as Genre and Signature" (Scandinavian Studies, 2017) og "Genresignaturen. En retorisk nydannelse" (Passage, 2015). Den trykte artikel er del af hans ph.d.-afhandling, der undersøger kreativ brug af genremærkater ud fra en genreteoretisk og litteratursociologisk synsvinkel.

\section{THE CAPITAL OF THE COVER}

An Empiric Study on the Significance of Genre Labels in the Valuation of Literary Works

Based on a large survey $(\mathrm{n}=539)$ this study examines how book covers in general and the genre label in particular play a role in the aesthetic positioning and marketing of books. A given work can succeed with large sales numbers and economic capital as well as by obtaining more field specific cultural and social capital. These different ways of positioning oneself on the market are, according to Bourdieu, to a large extent inverse - and it is therefore hypothesized that they require different strategies. In order to examine this phenomenon, the respondents are split into two groups and asked to evaluate four different covers with respect to broad audience appeal. Furthermore, they are asked to give a short description of the content they would expect in the different books. The cover samples are identical for the two groups, but alternating genre labels have been removed in one of the groups while being preserved in the other. Based on the responses, 
it is confirmed that genre labels have a significant effect on the reception of and expectations to the work. It is also demonstrated how the commercial and artistic appeal varies among the four books indicating an effect of the paratext as a whole. It is indicated by its cover, to what extent a book targets commercial interests or strives for a more field specific capital and recognition - and the genre label is a salient part of this positioning.

\section{KEYWORDS}

EN: the literary field, Bourdieu, reader response, marketing, genre theory, paratext, Genette, sociology of literature, genre labels, the book market

DK: det litterære felt, Bourdieu, læserrespons, marketing, genreteori, paratekst, Genette, litteratursociologi, genremærkater, bogmarkedet

\section{LITTERATUR}

Adler-Olsen, Jussi. Kvinden i buret: krimithriller. København: Politiken, 2013.

Behrendt, Poul, og Mads Bunch. Selvfortalt, autofiktioner på tværs: prosa, lyrik, teater, film. Frederiksberg: Dansklærerforeningen, 2015.

Bendsen, Pauline. "Fremmedgjorte træer og stirrende øjne". Information 4. marts 2016: $\mathrm{n}$. pag. https://www.information.dk/2016/03/fremmedgjorte-traeer-stirrende-oejne Benjamin, Walter. "Kunstværket i dets tekniske reproducerbarheds tidsalder". K\&K Kultur og Klasse 2277 (1994): 15-42.

Bjerring-Hansen, Jens, og Torben Jelsbak. Boghistorie. Århus: Aarhus Universitetsforlag, 2010.

Bourdieu, Pierre. La distinction: critique sociale du jugement. Paris:Éditions de Minuit, 1979.

Bourdieu, Pierre. Les règles de l'art: genèse et structure du champ littéraire. Paris: Editions du Seuil, 1992.

Bourdieu, Pierre. "Ökonomisches Kapital, kulturelles Kapital, soziales Kapital". Soziale Ungleichheiten. Red. Reinhard Kreckel. Göttingen: Schwartz, 1983. 183-198.

Bukdahl, Lars. "Hjernens rævegrav". Weekendavisen 8. marts 2013: n. pag.

Bukdahl, Lars. "Hun er vred over, at hun er vred". Weekendavisen 28. maj 2014: n. pag.

Christensen, Claus Handberg. "Det var en meget vigtig erfaring, at være anonym, Transnational adoption som tvungen migrationsform, Interview med Maja Lee Langvad". Monsieur Antipyrine 1 (2014): n. pag.

Christensen, Jeppe Krogsgaard. "Game, set og Madsen". Berlingske Tidende 9. marts 2014: n. pag. http://www.b.dk/boeger/game-set-og-madsen

Collins, Debbie. "Pretesting Survey Instruments: An Overview of Cognitive Methods". Quality of Life Research 123 (2003): 229-238. 


\section{JACOB ØLGAARD NYBOE COVERETS KAPITAL}

Dixon, Peter, Marisa Bortolussi og Blaine Mullins. "Judging a Book by its Cover". Scientific Study of Literature 51 (2015): 23-48.

Drennan, Jonathan. "Cognitive Interviewing: Verbal Data in the Design and Pretesting of Questionnaires". Journal of Advanced Nursing 421 (2003): 57-63.

Elmelund, Rasmus. "Et poetisk røntgenbillede". Information 4. marts 2016: n. pag. https://www.information.dk/kultur/2016/o3/poetisk-roentgenbillede

Field, Andy P. Discovering Statistics Using SPSS: (and Sex, Drugs and Rock " $n$ " Roll). 3. udg. Los Angeles: SAGE Publications, 2009.

Fowler, Alastair. Kinds of Literature: an Introduction to the Theory of Genres and Modes. Cambridge, Mass: Harvard University Press, 1982.

Garsdal, Lise. "Hvad kommer efter vrede?" Politiken 1. juni 2014: n. pag.

Gemzøe, Anker, Aalborg Universitet. Metamorfoser i mellemtiden: studier i Svend Åge Madsens forfatterskab 1962-1986. Holte: Medusa, 2004.

Genette, Gerard. Paratexts, Thresholds of Interpretation. Overs. Richard Macksey og Jane E. Lewin. Cambridge: Cambridge University Press, 1997.

Handesten, Lars. "Der er noget galt i Danmark: bidrag til kritikken af de danske kulturkløfter". SPRING - Tidsskrift for moderne dansk litteratur 40 (2017): 13-21.

Handesten, Lars. "Fantasiens ormehuller". Kristeligt Dagblad 8. marts. 2013: n. pag. https://www.kristeligt-dagblad.dk/kultur/fantasiens-ormehuller

Hjarvard, Stig. "Danskernes smag for litteratur". Passage-Tidsskrift for litteratur og kritik 3176 (2017): 145-167.

Høeg, Mette. "Dansk litteratur lider under kvindelige forfatteres dominans". Weekendavisen 8. maj 2015: n. pag.

Haarder, Jon Helt. "Himlen må vente". Jyllands-Posten 31. januar. 2005: n. pag.

Jørgensen, John Christian. "Mareridt". Ekstra Bladet 16. september. 2004: n. pag.

Keinicke, Mette. "Læseklubber på Gentofte Bibliotekerne 2015/2016". issuu, 2015: 12. https://issuu.com/mettekeinicke/docs/110437-gentofte_kommune-softproof

Kondrup, Johnny. "Tekst og værk - et begrebseftersyn". Betydning \& Forståelse. Red. Dorthe

Duncker, Anne Mette Hansen og Karen Skovgaard-Petersen. København: Selskab for Nordisk Filologi, 2013. 65-76.

Langvad, Maja Lee. Hun er vred: et vidnesbyrd om transnational adoption. København: Gladiator, 2014.

Lundblad, Kristina. Om betydelsen av böckers utseende: det svenska förlagsbandets framväxt och etablering under perioden 1840 - 1914 med särskild hänsyn till dekorerade klotband ; en studie av bokbandens formgivning, teknik och relation till frågor om modernitet och materiell kultur. Malmö: Rámus, 2010.

Madsen, Svend Åge. Pigen i cementblanderen, mikroman. København: Gyldendal, 2013. McGann, Jerome J. The Textual Condition. Princeton, N.J.: Princeton University Press, 1991. Miall, David S. Literary Reading: Empirical \& Theoretical Studies. New York, NY: Lang, 2007. Moran, Joe. Star Authors: Literary Celebrity in America. London: Pluto Press, 2000.

Moretti, Franco. "Style, Inc. Reflections on Seven Thousand Titles (British Novels, 17401850)". Critical Inquiry 361 (2009): 134-158.

http://www.jstor.org/stable/10.1086/606125?seq=1\#page_scan_tab_contents 
Nielsen, Lars Brix. "Sag uden lig". Weekendavisen 4. juli. 2014: n. pag.

Nielsen, Thomas. "Vi læser historisk mange krimier". Søndagsavisen 21. november. 2014. http://www.sondagsavisen.dk/underholdning/filmboegermusik/2014-11-21-vi-laeser-historisk-mange-krimier/

Nyboe, Jacob Ølgaard. "Genresignaturen. En retorisk nydannelse". Passage 74 (2015): 21-34.

Nyboe, Jacob Ølgaard. "'Den var ikke onkelagtig nok'. En empirisk undersøgelse af læserrespons på genresignaturer". European Journal of Scandinavian Studies (i peer review).

Palle, Henrik. "En mand vil til bunds". Jyllands-Posten 20. juni. 2014: n. pag.

Phillips, Angus. "How Books Are Positioned in the Market: Reading the Cover". Judging a Book by its Cover: Fans, Publishers, Designers, and the Marketing of Fiction. Red. Nicole Matthews og Nickianne Moody. Burlington, VT: Ashgate Pub, 2007. 19-30.

Piters, Ronald og Mia Stokmans. "Genre Categorization and its Effect on Preference for Fiction Books". Empirical Studies of the Arts 182 (2000): 159-166.

Rasmussen, Anders Juhl. "Genre and Paratext". Genre and... Red. Sune Auken, Anders Juhl Rasmussen og Palle Schantz. København: Ekbátana, 2015: 125-147.

Reinholdt, Merete. "Strisser på afveje". Berlingske 26. juni. 2014: n. pag.

Rosendahl, Mette. "Kærlighed, forbrydelser og ormehuller". Jyllands-Posten 14 apr. 2013: n. pag. http://www.b.dk/boeger/jesper-stein-har-det-som-krimiforfattere-ofte-mangler

Savage, Michael. Social Class in the 21st Century. London: Pelican, 2015.

Skyum-Nielsen, Erik. "Manden med mikseren". Information 8. marts 2013: n. pag. https:// www.information.dk/kultur/anmeldelse/2013/o3/manden-mikseren

Squires, Claire. Marketing Literature: The Making of Contemporary Writing in Britain. Basingstoke: Palgrave Macmillan, 2009.

Stougaard-Nielsen, Jakob. Scandinavian Crime Fiction. London; New York: Bloomsbury Academic, 2017.

Tetzlaff, Marie. "Effektiv bagatel". Politiken 25. september 2004: n. pag. http://politiken. $\mathrm{dk} /$ kultur/boger/skonlitteratur_boger/art4891579/Effektiv-bagatel

Thompson, John B. Merchants of Culture: the Publishing Business in the Twenty-First Century. Cambridge, UK ; Malden, MA: Polity, 2010.

Vinterberg, Søren. "Gensyn med sig selv". Politiken 8. marts 2013: n. pag.

Willis, Gordon B. Cognitive Interviewing: A Tool for Improving Questionnaire Design. London: Sage Publications, 2004.

http://www.dea.univr.it/documenti/OccorrenzaIns/matdid/matdid823948.pdf

Yampbell, Cat. "Judging a Book by its Cover: Publishing Trends in Young Adult Literature". The Lion and the Unicorn 293 (2005): 348-372.

Yde, Katrine Hornstrup. "Den slags vrede kan ændre verden". Information 30. maj 2014: n. pag. https://www.information.dk/kultur/anmeldelse/2014/05/slags-vrede-kanaendre-verden 